\title{
Packaging Considerations for Biopreservation
}

\author{
Erik J. Woods ${ }^{\text {a.b }}$ Sreedhar Thirumala ${ }^{a}$

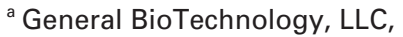 \\ ${ }^{\mathrm{b}}$ Department of Pediatrics, Herman B Wells Center for Pediatric Research, Indiana University School of Medicine, Indianapolis, IN, USA
}

\section{Keywords}

Biopreservation · Cryopreservation · Vials .

Closed system cryovials · Scaleable $\cdot$ Manufacturing .

Fill-finish $\cdot$ Mesenchymal stem cells

\section{Summary}

The packaging system chosen for biopreservation is critical for many reasons. An ideal biopreservation container system must provide for closure integrity, sample stability and ready access to the preserved material. This means the system needs to be hermetically sealed to ensure integrity of the specimen is maintained throughout processing, storage and distribution; the system must remain stable over long periods of time as many biobanked samples may be stored indefinitely; and functionally closed access systems must be used to avoid contamination upon sample withdraw. This study reviews the suitability of a new commercially available vial configuration container utilizing blood bag style closure and access systems that can be hermetically sealed and remain stable through cryopreservation and biobanking procedures. This vial based systems allow for current good manufacturing/tissue practice (cGTP) requirements during processing of samples and may provide the benefit of ease of delivery by a care giver. In this study, the CellSeal ${ }^{\circledR}$ closed system cryovial was evaluated and compared to standard screw cap vials. The CellSeal system was evaluated for durability, closure integrity through transportation and maintenance of functional viability of a cryopreserved mesenchymal stem cell model. The results of this initial proof-of-concept study indicated that the CellSeal vials are highly suitable for biopreservation and biobanking, and provide a suitable container system for clinical and commercial cell therapy products frozen in small volumes.

\author{
Schlüsselwörter \\ Biologische Konservierung · Kryokonservierung · \\ Reagenzröhrchen · Gefrierröhrchen mit geschlossenem \\ System · Befüllung · Mesenchymale Stammzellen
}

\section{Zusammenfassung}

Bei der biologischen Konservierung ist die Frage nach dem geeigneten Behältnis aus vielerlei Gründen wichtig: Ein ideales Behältnis für die biologische Haltbarmachung muss verschlussdicht sein, die Probenstabilität gewährleisten und schnellen Zugriff zum haltbar gemachten Material ermöglichen. Das bedeutet, dass das Behältnis hermetisch verschlossen sein muss, damit die Probe die Prozessierung, die Lagerung und den Distributionsprozess unbeschadet übersteht. Darüber hinaus muss es langzeitbeständig sein, da für viele eingelagerte Proben ein Ende der Aufbewahrungsfrist nicht absehbar ist, und es muss über ein funktionell geschlossenes System verfügen, um bei der Probenentnahme eine Kontamination zu vermeiden. In dieser Arbeit wird ein neues kommerziell verfügbares System in Röhrchen-Konfiguration vorgestellt, das über ein von Blutbeuteln her bekannten Verschluss- und Öffnungsprinzip verfügt, das hermetisch verschlossen werden kann und das während der Kryokonservierung und Einlagerung stabil bleibt. Das röhrchenbasierte System erlaubt das Arbeiten unter Beachtung der "current good manufacturing/tissue practice» (cGTP). In dieser Arbeit beschreiben wir die Untersuchung des CellSeal ${ }^{\circledR}$-Tiefkühlröhrchens und vergleichen es mit den üblichen Schraubdeckelröhrchen. Dabei wurde auf Haltbarkeit, Verschlussdichte während des Transports und die Aufrechterhaltung der Funktion mit mesenchymalen Stammzellen als Modellzellen untersucht. Die Ergebnisse dieser «Proof-of-principle»-Untersuchung zeigen die Eignung der CellSeal-Röhrchen für das biologische Haltbarmachen und die Lagerung für Produkte in kleineren Volumina für die klinische und kommerzielle Zelltherapie.

\begin{tabular}{ll}
\hline KARGER & $\oplus$ 2011 S. Karger GmbH, Freiburg \\
Fax+497614520714 & Accessible online at: \\
$\begin{array}{l}\text { Information@Karger.de } \\
\text { www.karger.com }\end{array}$ & www.karger.com/tmh
\end{tabular}

Erik J. Woods, Ph.D.

General BioTechnology, LLC

1102 Indiana Avenue, Indianapolis, IN 46202, USA

$+13179173450$

erik@gnrlbiotech.com 


\section{Introduction}

The ultimate goal in biopreservation is to develop biorepositories that have relevant material (e.g. cells, tissues, blood and bodily fluids such as plasma or serum) preserved in a stable format readily usable by investigators and/or clinicians. While some (particularly non-clinical) biobanks rely on mechanical freezers for storage, the most robust cryostorage medium available today is liquid nitrogen. Samples stored under liquid nitrogen are known to be at exactly $-196{ }^{\circ} \mathrm{C}$ and are not subjected to thermocycling, a possibility always inherent in vapor nitrogen storage or mechanical freezers. However, liquid nitrogen, like water, can act as a vehicle for the transmission of viruses, bacteria, fungi and animal cells. Thus, the container system chosen to store samples is of paramount importance, especially for non-fixed, liquid samples such as blood, other cell types or bodily fluids. For samples in storage for clinical utilization these issues take on additional safety importance. Therefore, an ideal biopreservation container system must provide for:

i) Closure integrity: The system needs to be hermetically sealed to ensure integrity of the specimen is maintained throughout processing, storage and distribution.

ii) Sample stability: The system must remain stable over long periods of time as many biobanked samples may be stored indefinitely.

iii) Easy access to material: Functionally closed access systems must be used to avoid contamination upon sample withdraw, and ideally sample recovery must easily automated. Additionally, as therapeutic cell products reach later stages of clinical trials, more consideration is being placed on manufacturing processes that are capable of meeting regulatory requirements for good manufacturing practices (GMP) and producing commercial-scale quantities of living cell products. Attention is being paid to the large-scale production of therapeutic cells [1] with downstream processing and fill-finish operations being cited as bottlenecks in current and future cell manufacturing [2].

Currently, many cell based products are stored in screw cap vials, a technology utilized for decades in research laboratories and sperm banks, or inbags, a technology borrowed from the blood banking industry. Screw cap vials have been used due to the relative ease and convenience of adding and removing samples, despite obvious drawbacks to the container closure integrity of these systems. Blood bags have been the container of choice for most cell therapy biopreservation due to the available infrastructure for processing, freezing and storage of these container systems. While blood bags are sufficient for small-scale processes that generate tens of product doses per lot, commercial-scale lot sizes of hundreds to thousands of living cell doses per lot will be required to supply a commercial scale cellular product, a volume which may preclude the use of bags. Additionally, many samples must be stored in smaller volumes than convenient in a bag format, and finally bag systems can be fragile at the extreme temperatures (and through the extreme temperature changes) imposed upon samples through biopreservation. These reasons make the use of a vial configuration more attractive.

The ideal vial based container system should not only be suitable for packaging and storage in biorepositories, it must also be useful for transport and even delivery of cell based products at low temperatures, while meeting pharmaceutical and medical device quality requirements to maintain cell viability over its intended shelf-life. Polypropylene is a plastic resin that has been used for decades in various packaging applications, including bags, tubes, bottles and other containers. However, these plastic resins have made minimal headway in the area of parenteral vials due to various quality attributes [3]. Recent availability of newer plastic resins [4] with key features such as glass-like clarity, lower potential extractables, ability for various modes of sterilization, very low moisture permeability, biocompatibility and lower particulates has enabled the use of these superior plastics for pharmaceutical and biopharmaceutical drug delivery applications. The use of these materials is only now being translated to cell based biologic products, due in part to the lack of data on the ability of cells to be successfully cryopreserved and stored while maintaining viability and important functionalities relevant to therapies over a reasonable shelf-life.

This study reviews the suitability of a new commercially available vial configuration container utilizing blood bag style closure and access systems that can be hermetically sealed and remain stable through cryopreservation and biobanking procedures. This vial based systems allow for current good manufacturing/tissue practice (cGTP) requirements during processing of samples and may provide the benefit of ease of delivery by a care giver. In this study, the CellSeal ${ }^{\circledR}$ closed system cryovial (CellSeal, Indianapolis, IN, USA) was evaluated and compared to standard screw cap vials. The CellSeal system was evaluated for durability, closure integrity through transportation and maintenance of functional viability of a cryopreserved cell model.

\section{Materials, Design and Description}

The majority of cell freezing bags currently available in the market are made primarily with ethylene vinyl acetate (EVA) and polyvinyl chloride (PVC). EVA experiences a glass transition temperature normally beginning at $-15{ }^{\circ} \mathrm{C}$ making its use questionable in environments below $-15^{\circ} \mathrm{C}$ [5]. This thermal transition of EVA makes freezing bags extremely brittle at temperatures that cell suspensions are typically stored. This results in the cell freezing bags being fragile and susceptible to breakage throughout cryopreservation processing and storage. This period of vulnerability includes the long-term storage of the cellular product, which can be measured in decades. Any failure of the cell freezing bag in this interval of vulnera- 


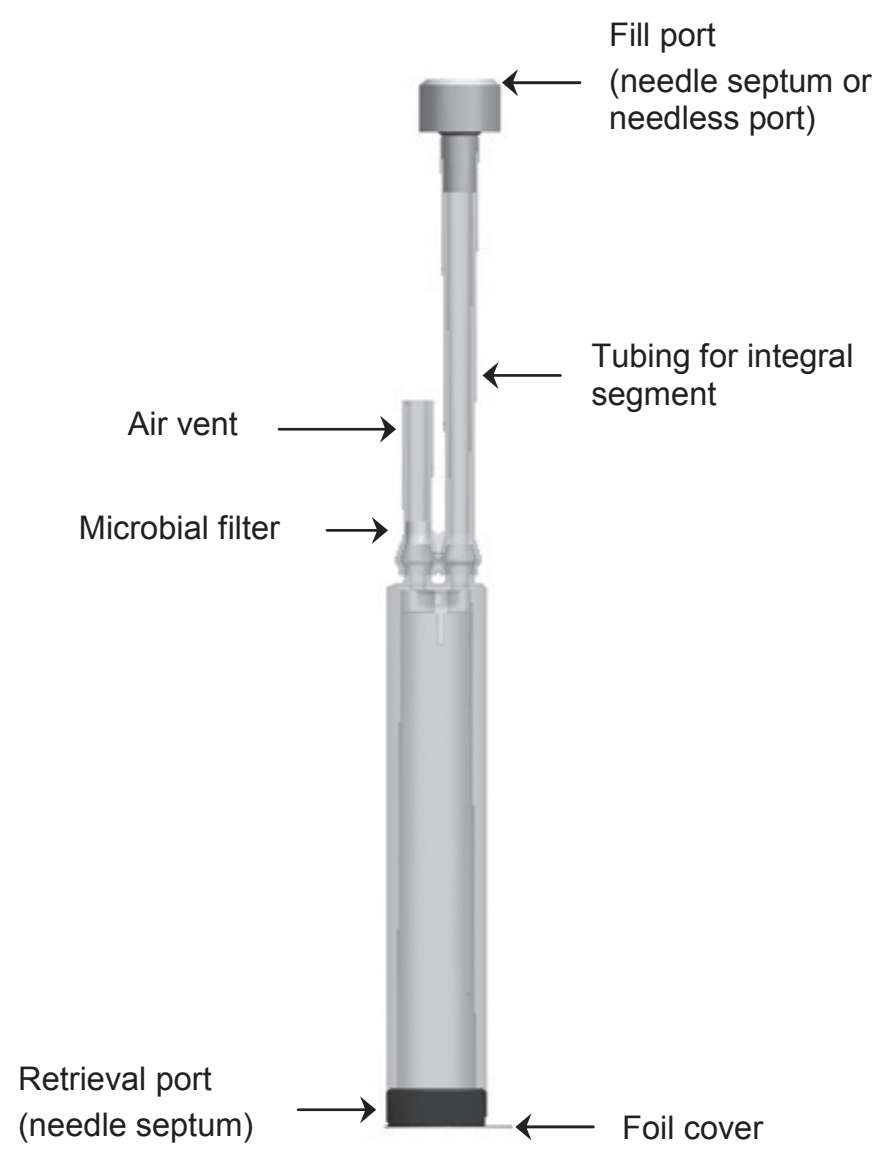

Fig. 1. Design and description of CellSeal vial system features.

bility will likely lead to the contamination of the contents and in turn can cross-contaminate other products stored in the same liquid nitrogen tank [6-8]. Another significant concern with many cell freezing bags is the extensive use of polyvinyl chloride (PVC) tubing for filling and retrieving sample from the bags. PVC tubing becomes brittle at typical cell suspension storage temperatures and will snap and easily break with even minimal force. Further, the plasticizers used in making PVC materials flexible are known to leach out of the plastic and into the surrounding media [9].

The CellSeal vials are constructed using USP class VI materials chosen specifically for their resistance to chemicals, drainability for maximum cell recovery and durability under cryogenic temperatures. The design of the CellSeal vial is shown in figure 1 . The CellSeal vial body is constructed from a commercially available cyclic olefin co-polymer (COC) (TOPAS $^{\circledR}$ COC; TOPAS Advanced Polymers GmbH, Frankfurt/M., Germany). COC resins are currently being used to package and deliver pharmaceutical drugs worldwide [1012]. With a variable glass transition temperature from $70{ }^{\circ} \mathrm{C}$ up to $177^{\circ} \mathrm{C}$ [13], COC is more break resistant at cryopreservation storage temperatures which helps reduce sample loss during filling, freezing, storage, shipping and retrieval. Being non-polar, COC has low moisture absorption and excellent drainability which prevents aqueous cell suspensions from adhering to the vial surface. It is compatible with a wide range of $\mathrm{pH}(2-12)$ and solvents such as alcohols, ketones and cellosolves. The material is highly transparent and has excellent thermal characteristics and can withstand liquid nitrogen exposures as well as sterilization by autoclaving.

The CellSeal system has three ports, and all the tubing associated with these ports is made of EVA. The first port is a needle or needleless septum at the end of a length of tubing used for filling the vial. This port is sealed using a standard blood bag heat sealer or radio frequency (RF) welder after introduction of the sample into the vial. The second port is actually an air vent and is fitted with a Porex ${ }^{\mathrm{TM}}$ filter plug made from polytetrafluroethylene (PTFE) (Porex Technologies, Fairburn, GA, USA) and tested to be biocompatible when used in medical applications [14]. The Porex plug acts as a microbial barrier vent to allow air to escape for easy fluid transfer without allowing the introduction of contaminants while filling or extracting. This tubing is sealed using the standard heat sealer or RF welder pre-freeze, then cut open post-thaw to aid in fluid extraction. The third port is a foil covered fixed needle septum at the distal end of the vial body for fluid extraction post thaw. The CellSeal vials are the same diameter of conventional cryovials which allows the use of conventional 'egg crate' cardboard or plastic separator boxes commonly used for the storage of standard cryopreservation tubes, which can be stored in standard clinical freezers (both vapor and liquid nitrogen). Two sizes, $2 \mathrm{ml}$ and $5 \mathrm{ml}$, of CellSeal vials were assessed in this study.

\section{Durability, Closure Integrity and Sterility Maintenance}

Durability (break resistance) and container closure integrity of CellSeal vials containing frozen solutions were evaluated by subjecting them to a 1-meter drop test followed by a dye penetration check. For this test, vials were filled to full capacity with a $10 \%$ solution of dimethyl sulfoxide (DMSO) (all reagents were from Life Technologies Corporation unless otherwise states) in phosphsate buffered saline (PBS) before the flexible tubing were heat sealed. Vials were then cryopreserved utilizing a dump-freeze method in a $-85^{\circ} \mathrm{C}$ mechanical freezer. After $24 \mathrm{~h}$ vials were transferred to the liquid nitrogen storage tank. At the appropriate time point, vials were taken out from storage and dropped, while still frozen, from a height of $1 \mathrm{~m}$ on an epoxy-coated concrete laboratory floor. Dropping was done by holding the vials on a $1 \mathrm{~m}$ high platform by a set of pliers, at an angle of $15^{\circ}$ to vertical, and then releasing them. After the drop, the vials were thawed rapidly by immersing them in a $37^{\circ} \mathrm{C}$ water bath, following which they were wiped clean with a lint-free wipe and inspected visually for any gross damage before being subjected to a dye penetration test. Vials were kept immersed in a $10 \%$ solution (v/v) of FD and C Red No. 40 dye in water for $1 \mathrm{~h}$, removed, wiped with a lintfree wipe and inspected for any evidence of dye penetration 
through cracks or around the seal. The normally clear contents of the vials were also visually inspected for optical clarity. To further assess the possibility of dye penetration through cracks or the seal, after drop test and dye immersion, each vial contents were compared to a freshly prepared solution of $10 \%$ (v/v) DMSO in PBS using a spectrophotometer. A 10\% solution $(\mathrm{v} / \mathrm{v})$ of the dye in PBS was used as a positive control. The wavelength of maximum absorbance was set to $525 \mathrm{~nm}$. For the measurements, a $1 \mathrm{ml}$ sample was taken from each vial in a cuvette, which was placed in the spectrophotometer (Beckman DU-7500, Beckman Coulter, Inc., Fullerton, CA), and absorbance at the set wavelength was measured.

The 1-meter drop tests indicated that the freezing process to $-196{ }^{\circ} \mathrm{C}$ did not affect the mechanical strength and integrity of the CellSeal vial systems. After drop testing, no visual evidence of gross external damage was observed on the vial surfaces, tubing or seals. The solution inside the vials was optically clear after dye immersion test, confirming that there was no dye ingress into the vials through cracks, perturbed joints or sealing. This conclusion was further confirmed by the results of the spectrophotometer tests which showed no significant absorbance at the set wavelength for any given storage time and temperature.

\section{Sterility Testing after Freezing, Shipping and Thawing}

To ensure that the CellSeal vials could maintain closure integrity through freezing, storage, shipping and thawing processes, container closure integrity studies (dye ingress and microbial challenge tests) were performed in conjunction with an outside contract testing laboratory (Nelson Labs, Salt Lake City, UT, USA).

For the dye immersion test, vials were filled with isotonic PBS solution containing 10\% DMSO and the flexible tubing was sealed. For sterility maintenance test, vials were filled with tryptic soy broth (TSB) and then closed appropriately. Before being shipped for testing, vials were control cooled to $-85^{\circ} \mathrm{C}$ and then plunged into a $-196{ }^{\circ} \mathrm{C}$ liquid nitrogen tank. After 1 week, vials were shipped interstate to Nelson Labs using a dry shipper. Upon receipt at the laboratory, the samples were thawed in a water bath at $37{ }^{\circ} \mathrm{C}$ until last bit of ice just melted, after which they were wiped and air dried for testing. The dye immersion test was performed by immersing vials in a solution of methylene blue dye and Polysorbate $\left(\right.$ Tween $^{\circledR}$ ) 80 and subjected to a pressure differential. The contents of each vial were examined for evidence of dye penetration by the use of a UV/Vis spectrophotometer. A vial passed if the maximum absorbance of the sample was less than the maximum absorbance of the sample used to determine the detection limit. Next, to evaluate the microbiological barrier properties of TSB filled vials following low temperature storage and shipping, the vials were brought to room temperature by thawing in a $37^{\circ} \mathrm{C}$ water bath and tested by immersing them into a microbial challenge 'bath' of Brevundimonas diminuta, American Type Culture Collection (ATCC) \#19146, for a specified amount of time while subjecting the test sample to pressure changes. The selection of $B$. diminuta as the challenge organism is based on its very small size when grown under carefully controlled conditions. Due to the size and concentration of organisms in the challenge solution, $B$. diminuta represents a most stringent bacterial challenge. The vials were then removed from the microbial challenge solution, rinsed, incubated and examined for growth of the challenge organism. A bacteriostasis test was performed on selected sterile containers post incubation to demonstrate that the test system and materials did not inhibit the growth of the challenge organism. Positive controls were made by piercing a single hole in the top vials using a 22 gauge needle. The positive controls were then tested in the same manner as the test containers. Negative controls consisted of filled test samples which were not exposed to the challenge solution.

No evidence of dye penetration was detected for all vials frozen, stored and shipped at $-196^{\circ} \mathrm{C}$. Additionally, each of the CellSeal vials passed the integrity test and gave sterile effluent when challenge tested. Positive controls had both dye and bacterial penetration, whereas negative controls had no dye or bacterial penetration verifying the validity of the test methods.

\section{Performance Testing by Mesenchymal Stem Cell Banking}

As a stem cell model, a mesenchymal stem cell (MSC) population isolated from human dental pulp tissue with characteristics similar to bone marrow MSC in terms of their gene expression profiles and expression of cell surface markers was utilized [15-16]. These dental pulp derived MSC (or DPSC) have been well characterized in our laboratory and possess the capacity to differentiate into osteoblasts, chondrocytes, adipocytes, muscle cells and neural cells [16-18]. Tremendous interest has been generated in the potential use of MSC and DPSC for tissue regeneration and cellular therapies. Our group [16-17] and others [18-19] have shown that DPSC can be successfully cryopreserved and thawed with good retention of functional viability. Because of these properties and their ready availability, DPSC cultures at low passages (P1-P4) were used to evaluate the performance of Cellseal vials to maintain a cryopreserved cell model. For these experiments, a standard screw cap cryovial was used as a control.

The human DPSC stem cells were isolated and expanded as described elsewhere $[15,17,19]$. Briefly, the human 3rd molars from males and females aged 18-26 years were extracted using standard techniques from a local oral surgery group. Discarded, de-identified teeth were placed in a hypothermic preservation medium (HTS; BioLife Solutions, Bothell, WA, USA) and couriered, on ice, to the laboratory on the day of extraction. Once at the lab, DPSC were isolated and 
Table 1. Viability analysis of post-thaw DPSCs cryopreserved in CellSeal vials when compared to standard corning cryovials (the viability was normalized to pre-freeze values)

\begin{tabular}{|c|c|c|c|c|c|c|c|c|}
\hline \multirow[t]{3}{*}{ Size } & \multicolumn{4}{|l|}{ Passage 1} & \multicolumn{4}{|l|}{ Passage 4} \\
\hline & \multicolumn{2}{|l|}{ donor 1} & \multicolumn{2}{|l|}{ donor 2} & \multicolumn{2}{|l|}{ donor 3} & \multicolumn{2}{|l|}{ donor 4} \\
\hline & CellSeal & control & CellSeal & control & CellSeal & control & CellSeal & control \\
\hline $2 \mathrm{ml}$ & $82.7 \pm 4.0$ & $90.2 \pm 1.2$ & $90.8 \pm 3.3$ & $92.0 \pm 1.8$ & $87.8 \pm 9.2$ & $94.0 \pm 1.0$ & $94.0 \pm 3.1$ & $93.9 \pm 3.1$ \\
\hline $5 \mathrm{ml}$ & $85.3 \pm 2.8$ & $82.3 \pm 2.7$ & $87.7 \pm 7.6$ & $90.6 \pm 6.6$ & $91.0 \pm 3.8$ & $93.8 \pm 0.6$ & $92.0 \pm 3.2$ & $88.7 \pm 2.6$ \\
\hline
\end{tabular}

Established, expanded DPSC were frozen using a standard cryopreservation protocol, which consisted of a two-step equilibration to a final concentration of $10 \%$ DMSO (Cryoserv, Edwards Lifesciences, Irvine, CA, USA) prepared in complete Mesencult ${ }^{\mathrm{TM}}$ medium (Stem Cell Technologies, Vancouver, BC, Canada). The equilibration steps consisted of a gradual addition of half the volume of $20 \%$ DMSO to a volume of cell suspension (over $5 \mathrm{~min}$ ), followed by a quick addition (over $1 \mathrm{~min}$ ) of one half the volume of $20 \%$ DMSO to cell suspension, for the final concentration of $10 \%$ DMSO in cell suspension.

Control vials ( $2 \mathrm{ml}$ polypropylene; Corning, Corning, NY, USA) were aseptically filled in a biosafety hood with the equilibrated cell suspension. For Cellseal vials, both $2 \mathrm{ml}$ and $5 \mathrm{ml}$ vials were aseptically filled using a syringe through needle septum at the end of the flexible tubing (fig. 1). Both experimental and control vials were filled at a concentration of $1 \times 10^{6}$ cells $/ \mathrm{ml}$. The vials were then cryopreserved utilizing a modified dump freezing method by placing vials in insulated boxes rated for a cooling rate of $-1{ }^{\circ} \mathrm{C} / \mathrm{min}$ within a $-85^{\circ} \mathrm{C}$ mechanical freezer for $12 \mathrm{~h}$ (VIP Series Ultra-Low Temperature Freezer; Sanyo Scientific, Bensenville, IL, USA). Once frozen, the vials were removed from the $-85^{\circ} \mathrm{C}$ mechanical freezer and plunged into a liquid nitrogen storage tank for storage at $-196^{\circ} \mathrm{C}$ (Cryomed CryoPlus II; Thermo Fisher Scientific, Waltham, MA, USA). Vials then remained at $-196{ }^{\circ} \mathrm{C}$ storage for 1 week.

At the appropriate time point the vials were retrieved from $-196{ }^{\circ} \mathrm{C}$ storage and thawed in a $37{ }^{\circ} \mathrm{C}$ water bath. The time of initial onset of thaw until the last of the ice just melted was measured and recorded to estimate thermal transfer characteristics. To wash the cells and prepare them for viability testing, the suspension was initially diluted with DMSO free Mesencult complete medium at a $1: 1 \mathrm{v}: \mathrm{v}$ ratio over $10 \mathrm{~min}$, centrifuged at $500 \times \mathrm{g}$ for $10 \mathrm{~min}$ and then resuspended in fresh Mesencult complete medium to complete the washing process.

Immediate post-thaw viability was measured using a standard trypan blue dye exclusion assay [20]. Briefly, $10 \mu \mathrm{l}$ of concentrated cell suspension from a representative vial from each set was mixed with an equal volume of trypan blue (Sigma) in a tube and allowed to sit for $5 \mathrm{~min}$. Next, $10 \mu \mathrm{l}$ of dyed cell suspension was pipetted into the counting chamber. Cells stained blue were considered non-viable, clear cells were considered viable. To measure functionality, time to confluence and doubling rates were measured using standard cell culture 
Table 2. Time (days) taken days by the pre-freeze and postthaw DPSCs to reach $70-80 \%$ confluence

\begin{tabular}{|c|c|c|c|c|c|c|c|c|}
\hline & \multicolumn{8}{|c|}{ Pre-freeze } \\
\hline & \multicolumn{4}{|c|}{ Passage 1} & \multicolumn{4}{|c|}{ Passage 4} \\
\hline & \multicolumn{2}{|l|}{ donor 1} & \multicolumn{2}{|l|}{ donor 2} & \multicolumn{2}{|l|}{ donor 3} & \multicolumn{2}{|l|}{ donor 4} \\
\hline & \multicolumn{2}{|l|}{6} & \multicolumn{2}{|l|}{4} & \multicolumn{2}{|l|}{4} & \multicolumn{2}{|l|}{4} \\
\hline \multirow[t]{4}{*}{ Size } & \multicolumn{8}{|c|}{ Post-freeze } \\
\hline & \multicolumn{4}{|c|}{ Passage 1} & \multicolumn{4}{|c|}{ Passage 4} \\
\hline & \multicolumn{2}{|l|}{ donor 1} & \multicolumn{2}{|l|}{ donor 2} & \multicolumn{2}{|l|}{ donor 3} & \multicolumn{2}{|l|}{ donor 4} \\
\hline & CellSeal & control & CellSeal & control & CellSeal & control & CellSeal & control \\
\hline $2 \mathrm{ml}$ & 5.5 & 5 & 4.5 & 5 & 3.5 & 5 & 4 & 5 \\
\hline $5 \mathrm{ml}$ & 5.5 & 6 & 5 & 5 & 4 & 3 & 3.5 & 4 \\
\hline
\end{tabular}

techniques [20] as we previously described [16]. Once harvested, the thawed and expanded cultures were re-examined by flow cytometry to ensure there was no change in cellspecific markers due to exposure to the CellSeal containers or cryopreservation protocols (data not shown).

The initial DPSC cultures, prior to manipulation and cryopreservation in the various vials, exhibited standard doubling rates of approximately 2 days, expressed cell surface antigens and underwent multilineage differentiation indicative of MSC $[19,21]$. In CellSeal vials, the DPSC samples showed a viability range of $82.3 \pm 2.7$ to $94.0 \pm 3.1$ (table 1 ). These data indicated no donor or passage variation in post-thaw viability of DPSCs either frozen in CellSeal or control vials.

Frozen-thawed cells exhibited rapid recovery with cells beginning to adhere to the culture flask and regain morphology in as little as $2 \mathrm{~h}$ post-thaw. All cultures became $~ 70 \%$ confluent within 4-6 days, consistent with our prior work $[16,17]$ and similar to non-frozen controls, indicative of recovery of proliferative potential of DPSCs stored in both vials (fig. 2). No contamination was evident in any of the cultures via visual observation.

Time to confluence for the DPSCs frozen in CellSeal and related control vials is given in table 2 . On average the postthawed cells took 3-5.5 days when frozen in CellSeal and 3-6 days when frozen in control vials to reach $70-80 \%$ confluence. These values are statistically in agreement with each other and also with pre-freeze values (4-6 days).

\section{Discussion}

Liquid nitrogen, like water, can act as a vehicle for the transmission of viruses, bacteria, fungi and animal cells. The realization that liquid nitrogen exposed to viruses should be treated as a biohazard is not new [22] and is indicative of the potential contamination problems that liquid nitrogen may present. A tragic example of this phenomena occurred when bone marrow stem cells harvested from patients undergoing cytotoxic treatment became contaminated with $\mathrm{HBV}$ as a result of storage in liquid nitrogen and caused an HBV outbreak by transmission to other stored units [23]. Of the 6 patients afflicted, human DNA, hepatitis B surface antigen A and HBV DNA matching those patients were found in the liquid nitrogen. The interesting observation is that DNA from the patients, and thus presumably their cells, was found in the liquid nitrogen indicating that contaminants move both in and out of the storage containers. A follow-up study to this HBV outbreak confirmed the human and HBV sources by DNA sequence analysis [24].

Other viruses have previously been found to survive direct exposure to liquid nitrogen, including vesicular stomatitits virus [22], herpes simplex virus, adenovirus [25], and papilloma virus [26, 27]. Foutain et al. [6] conducted a survey of fungal and bacterial contamination of liquid nitrogen freezers used to store hematopoietic stem cells. Of the 583 cultures tested, $1.2 \%$ were found to be contaminated by microorganisms. However, four of five freezers examined contained low-level microbial contamination, while the fifth freezer was heavily contaminated with Aspergillus. The microbial contamination found in the freezers was similar to the microbes found in the contaminated cultures. Though not citing the liquid nitrogen as the microbial source, other reports demonstrated the common occurrence of microbial contamination of cryopreserved stem cells [28-31]. For these reasons, container integrity is now considered a critical issue for maintaining sterility and viability of cryopreserved cellular therapy products. With the emergence of cellular therapy as a more widely used clinical practice, improved containers and closure systems for effective safe use and cell preservation are required.

The submersion of screw capped plastic vials allows for contact between contaminated liquid nitrogen and the sample. At temperature, condensation of the atmosphere within the vial creates a vacuum which can draw in the liquid nitrogen. Any contaminants in this medium may therefore contaminate the sample. Cell freezer bags can be hermetically sealed; for this and several other reasons, including the fact that many cell banks evolved from blood banks, freezing bags are currently preferred over vials for storage and shipping cells to clinical sites. 
Although bags have been proven effective in many indications, especially when relatively large volumes are required, recently there has been more focus on the shortcomings of this system. A study [7] investigated a series of catastrophic bag failures first noticed in 2001. In that study, high rates of bag failure were associated with four specific bag lots made from polyethylene co-vinyl acetate. While no serious adverse patient effects occurred, extensive fractures led to microbial contamination, increased product preparation time, increased antibiotic use and increased resource expenditure to replace products. In another study, loss of integrity of $3.5 \%$ of the bags was reported with cord blood unit cryopreservation when investigated from 2000 to 2006. Most of these breaks were observed during thawing of the bags at $37^{\circ} \mathrm{C}$ [32]. These kinds of bag failures may have been more common than observed [32]. Further, bags are not a suitable choice for smallvolume samples when required to store under aseptic conditions. Because of the relatively brittle nature of the material most bags are constructed of, sample stability at temperature may be compromised, especially during transport and manipulation of the sample during thaw.

Our group recently evaluated the use of pharmaceuticalstyle vials for cell cryopreservation that appeared to have the benefit of a closed system as well as a robust nature at temperature [2]. These vials, like the CellSeal system, were manufactured from COC: however, they utilized stoppered closures comparable to parenteral drug containers. This concept offers many benefits and conveniences for biopreservation of a wide range of sample volumes and can potentially allow the leverage of existing pharmaceutical packaging technology including large-scale fill-finish for manufacture. However, since stoppered systems remain closed post thaw, a quick vacuum buildup can occur in the vial body during sample extraction that can make sample recovery very difficult and potentially damaging to cell viability and function, especially in smaller volumes. This downside has been completely eliminated in the design of the CellSeal system which has the benefits of closure integrity and sample stability as well as easy access to the sample post thaw. This system permits filtered air to enter vial to prevent vacuum buildup and thus assists with the smooth flow and complete extraction of sample. The various sizes of pharmaceutical-type vials also do not readily fit in existing biobanking box, rack and shelf systems. The CellSeal system, having the same diameter of standard cryovials, allows for recognized storage options in the biobank.

\section{Conclusions}

In this study, all cell cultures remained free of contamination throughout the test cycle, indicating aseptic sample preparation and effective vial closure system at cryogenic temperatures. From a mechanical stand point, CellSeal vials exhibited no gross breakage or cracking after drop testing indicating their excellent mechanical strength and durability.

The shipping tests provided further practical evaluation of the integrity of the vial system under standard transport condition under a typical use scenario (e.g. shipping a frozen product in dry shipper) coupled with very stringent testing of the closure system following pressure cycling after receipt, storage and thaw. In these tests, none of the CellSeal vials displayed any microbial ingress.

Overall, this initial proof-of-concept study indicated that the CellSeal vials are highly suitable for biopreservation and biobanking, and provide a suitable container system for clinical and commercial cell therapy products frozen in small volumes. Bag configurations may remain the best option for larger volumes, and inherent issues with durability at temperature may be mitigated by the use of overwraps. Pharmaceutical-style vials may be a viable option for large-scale manufacture; however, end user issues with cell retrieval must be managed.

\section{Acknowledgements}

This work was funded by grants from the NIH-NCRR (2R44RR024962-02 to EJW) and by General BioTechnology, LLC.

\section{Disclosure Statement}

Both authors are employees of General BioTechnology, LLC.

\section{References}

1 Kirouac DC, Zandstra PW: The systematic production of cells for cell therapies. Cell Stem Cell 2008; 3:369-381.

2 Woods EJ, Perry BC, Hockema JJ, Larson L, Zhou W, Goebel WS: Optimized cryopreservation method for human dental pulp derived stem cells and their tissues of origin for banking and clinical use. Cryobiology 2009;59:150-157.

3 Akers MJ, Nail SL, Saffell-Clemmer W: Top ten topics in parenteral science and technology. PDA J Sci Technol 2007;61:337-361.
4 Eakins MN: New plastics for old vials. Bioprocess Int 2005;3:52-58.

5 Kempe MD, Jorgensen GJ, Terwilliger KM, McMahon TJ, Kennedy CE, Borek TT: Acetic acid production and glass transition concerns with ethylenevinyl acetate used in photovoltaic devices. Solar Energy Materials Solar Cells. 2007;91:315-329.

-6 Fountain D, Ralston M, Higgins N, Gorlin JB, Uhl L, Wheeler C, et al: Liquid nitrogen freezers: a potential source of microbial contamination of hematopoietic stem cell components. Transfusion 1977;37:585-591.
7 Khuu HM, Cowley H, David-Ocampo V, et al: Catastrophic failures of freezing bags for cellular therapy products: description, cause, and consequences. Cytotherapy 2002;4:539-549.

8 Thirumala S, Goebel WS, Woods EJ: Clinical grade adult stem cell banking. Organogenesis 2009;5:143-154.

9 Messori M, Toselli M, Pilati F, Fabbri E, Fabbri P, Pasquali L, Nannarone S: Prevention of plasticizer leaching from PVC medical devices by using organicinorganic hybrid coatings. Polymer 2004;45:805-813. 
10 Qadry SS, Roshdy TH, Char H, Del Terzo S, Tarantino R, Moschera J: Evaluation of CZ-resin vials for packaging protein-based parenteral formulations. Int J Pharm 2003;252:207-212.

11 Esfandiary R, Joshi SB, Vilivalam V, Middaugh $\mathrm{CR}$ : Characterization of protein aggregation and adsorption on prefillable syringe surfaces. Presented at the AAPS National Biotechnology Conference, Toronto, June 22-25, 2008.

12 Waxman L, Vilivalam V: Development of analytical techniques to determine protein adsorption on sterilized parenteral packaging containers and stoppers. Presented at AAPS National Biotechnology Conference. Seattle, WA, June 21-24, 2009.

13 Shin JY, Park JY, Liu C, He J, Kim SC: Chemical structure and physical properties of cyclic olefin copolymers. International Union of Pure and Applied Chemistry (IUPAC) Technical Report. Pure Appl Chem 2005;77:801-814.

14 Risbud MV, Hambir S, Jog J, Bhonde R: Biocompatibility assessment of polytetrafluoroethylene/ wollastonite composites using endothelial cells and macrophages. J Biomater Sci Polym Ed 2001;12 1177-1189.

15 Shi S, Robey PG, Gronthos S: Comparison of human dental pulp and bone marrow stromal stem cells by cDNA microarray analysis. Bone 2001;29: 532-539.

16 Perry BC, Zhou D, Xiaohua W, Yang FC, Byers MA, Chu TM, Hockema JJ, Woods EJ, Goebe WS: Collection, cryopreservation and characterization of human dental pulp derived mesenchyma stem cells for banking and clinical use. Tissue Eng 2008;14:149-156.
17 Woods EJ, Bagchi A, Goebel WS, Vilivalam VD, Vilivalam VD: Container system for enabling commercial production of cryopreserved cell therapy products. Regen Med 2010;5:659-667.

18 Seo BM, Miura M, Sonoyama W, Coppe C, Stanyon R, Shi S: Recovery of stem cells from cryopreserved periodontal ligament. J Dental Res 2005; 841:907-912.

19 Zhang W, Walboomers XF, Shi S, Fan M, Jansen JA: Multilineage differentiation potential of stem cells derived from human dental pulp after cryopreservation, Tissue Eng 2006;12:2813-2823.

20 Freshney RI: Culture of Animal Cells: A Manual of Basic Technique. New York, Wiley and Sons, 2000.

21 Dominici M, Le Blanc K, Mueller I, Slaper-Cortenback I, Marini FC, Krause DS, Deans RJ, Prockop DJ, Horwitz EM: Minimal criteria for defining multipotent mesenchymal stromal cells. The International Society for Cellular Therapy position statement. Cytotherapy 2006;8:315-317.

22 Shafer TW, Everett J, Silver GH, Came PE: Biohazard: virus-contaminated liquid nitrogen. Science 1976;191:24-26.

23 Tedder R, Zuckerman M, Goldstone A, Hawkins A, Fielding A, Briggs E, Irwin D, Blair S, Gorman A, Patterson K, Linch D, Heptonstall J, Brink N: Hepatitis B transmission from contaminated cryopreservation tank. Lancet 1995;346:137-140.

24 Hawkins A, Zuckerman M, Briggs M, Gilson R, Goldstone A, Brink N, Tedder R: Hepatitis B nucleotide sequence analysis: linking an outbreak of acute hepatitis B to contamination of a cryopreservation tank. J Virol Methods 1996;60:81-88.
5 Jones SK, Darville JM: Transmission of virus particles by cryotherapy and multi-use caustic pencils: a problem to dermatologists? Br J Dermatol 1989; 121:481-486.

26 Goodman J: Liquid nitrogen therapy of warts and other skin lesions. Can Med Assoc J 1960;82:628630.

27 Charles CR, Sire DJ: Transmission of papillomavirus by cryotherapy application. J Am Med Assoc 1971;218:1435.

28 Prince H, Page S, Keating A, Saragosa R, Yukovic N, Imrie K, Crump M, Stewart A: Microbial contamination of harvested bone marrow and peripheral blood. Bone Marrow Transplant 1995;15:87-91.

29 Lazarus H, Magalhaes-Silverman M, Fox R, Creger $\mathrm{R}$, Jacobs M: Contamination during in vitro processing of bone marrow for transplantation: clinical significance. Bone Marrow Transplant 1991;7:241-246.

30 Stroncek D, Fautsch S, Lasky L, Hurd D, Ramsay $\mathrm{N}$, McCullough $\mathrm{J}$ : Adverse reactions in patients transfused with cryopreserved marrow. Transfusion 1991;31:521-526.

31 Webb I, Coral F, Anderson J, Elias A, Finberg R, Nadler L, Ritz J, Anderson K: Sources and sequelae of bacterial contamination of hematopoietic stem cell components: implications for the safety of hematotherapy and graft engineering. Transfusion 1996;36:782-788.

32 Thyagarajan B, Berger M, Sumstad D, McKenna DH Jr: Loss of integrity of umbilical cord blood unit freezing bags: description and consequences. Transfusion 2008;48:1138-1142. 